\title{
PERFORMANCE OF BEEF COWS OF DIFFERENT GENETIC GROUPS IN NATURAL AND CULTIVATED PASTURES
}

\author{
PASTAGENS NATURAIS E CULTIVADAS NO DESEMPENHO DE VACAS DE \\ CORTE DE DIFERENTES GRUPOS GENÉTICOS
}

\section{Ricardo Zambarda VAZ ${ }^{1}$; João RESTLE ${ }^{2}$; Fabiano Nunes VAZ ${ }^{3}$; Paulo Santana PACHECO ${ }^{4}$; José Neuman Miranda NEIVA ${ }^{5}$; Leonir Luiz PASCOAL ${ }^{4}$; Dari Celestino ALVES FILHO ${ }^{4}$; Patrícia Alessandra Meneguzzi Metz DONICHT ${ }^{6}$}

1. Professor Adjunto, Departamento de Zootecnia - Universidade Federal de Pelotas, Pelotas, RS, Brasil. rzvaz@terra.com.br; 2. Professor, Doutor, Programa de pós-Graduação em Ciência Animal Tropical - Universidade Federal do Tocantins, Araguaína, TO, Brasil; 3. Professor Adjunto, Departamento de Economia Rural - Universidade Federal de Santa Maria - UFSM, Santa Maria, RS, Brasil; 4. Professor Adjunto, Departamento de Zootecnia - UFSM, Santa Maria, RS, Brasil; 5. Professor Adjunto, Departamento de Zootecnia - Universidade Federal do Tocantins, Araguaína, TO, Brasil; 6. Professor Adjunto, Instituto Federal Farroupilha, Campus de Alegrete, RS, Brasil.

\begin{abstract}
The objective was to assess the performance of 96 pregnant cows of the genetic groups (GG) Charolais (C), Nellore $(\mathrm{N}), 1 / 2 \mathrm{CN}$ and $1 / 2 \mathrm{NC}$, subjected to the following treatments: kept exclusively in natural pastures (NP) throughout the experimental period; kept in cultivated pastures (CP) from July 15 to Setp 15 (CPNP) or from Sept 15 to Nov 15 (NPCP) and the remainder of the experimental period in NP. The weight at the end of the first grazing period (Sept 15) was higher for the CPNP cows than those of the NPCP and NP. The weight at the end of the second period (Nov 15) was 456, 428 and $392 \mathrm{~kg}$ respectively for NPCP, CPNP and NP. At calving, the heaviest cows were the CPNP, followed by the NPCP and the NP. At weaning, 90 days postpartum, the heaviest were the NPCP, followed by the CPNP and NP. Nelore cows were less heavy in all evaluations, followed by C, with the F1s' weight higher than the purebreds. The grazing sequences did not affect the percentages of the cows in estrus and pregnancy, but did influence the invervals between calving and first estrus postpartum (ICE). The GG influenced the rate of cows in estrus, pregnant and the ICE which was lower in the F1 (103 days), followed by the C (109 days) and had the largest interval N (119 days). The grazing sequences affect the average daily weight gain (ADG) of calves until weaning at 90 days of age. The GG of the calf affected the ADG at to 210 days.
\end{abstract}

KEYWORDS: Charolais. Crossbreeding. Estro. Heterosis. Nellore. Pregnancy.

\section{INTRODUCTION}

The low birth rates in addition to adversely affecting the offtake and productivity indicators of the herds (BERETTA et al., 2002), reduce the possibility of genetic improvement through selection due to low availability of replacement females (VAZ; LOBATO, 2010). The animals are born with their sexual behavior linked to factors related to the genetic load itself, but these factors interact with the environment promoting or inhibiting their reproductive behavior (VAZ et al., 2012).

Their reproductive performance is related to the management, health care and nutritional level to which they are subjected. This fact is accentuated in the southern part of Brazil where most of the cattle farms are built on natural pastures, the main source of feed for the livestock, where low production and quality limit the genetic potential response of the animals (RESTLE et al., 2005). With the nutritional deficit imposed on livestock rearing by overloading the animals per hectare (FAGUNDES et al., 2003), the cows arrive at calving with a low average body condition, and with lactation the body condition score decreases even more, not having the minimum conditions to return to reproductive activity in the subsequent breeding season.

Other important factors for better reproductive performance are the breed of animals and the use of crossbreeds aimed at achieving complementarily of desirable characteristics. Studies show the benefits of using crossbreeding to reduce the age of puberty as well as for the subsequent reproductive performance in beef cows (RESTLE et al., 2003).

The objective of this study was to assess the effect of the different grazing sequences considered as the periods of greatest nutritional demand on the maternal ability and reproductive performance of Charolais, Nellore and their F1 crossbreeds. 


\section{MATERIAL AND METHODS}

The experiment was conducted in the Animal Science Department of the Universidade Federal de Santa Maria - RS, located in the Depressão Central, at an altitude of $153 \mathrm{~m}$, which according to the Köppen classification, has a humid subtropical climate (cfa). The average annual temperature varies from 14.3 to $25.2^{\circ} \mathrm{C}$, with a minimum average of $9.7^{\circ} \mathrm{C}$ in August and a mean maximum of $29.9^{\circ} \mathrm{C}$ in January with possible frosts from April to October. The average relative humididty is $73 \%$ and rainfall is of $1650.9 \mathrm{~mm}$.

Ninety-six cows selected at random from the same experimental herd were used, aged three to ten years, from Charolais $(\mathrm{C})$, Nellore $(\mathrm{N}), 1 / 2 \mathrm{C} 1 / 2 \mathrm{~N}$ and $1 / 2 \mathrm{~N} 1 / 2 \mathrm{C}$, which produced pure $\mathrm{C}$ or $\mathrm{N}$ calves, or crossbreds $1 / 2 \mathrm{C} 1 / 2 \mathrm{~N}, 3 / 4 \mathrm{C} 1 / 4 \mathrm{~N}$ (sired by $\mathrm{C}$ bulls) or $1 / 2 \mathrm{~N}^{1 / 2} \mathrm{C}, 3 / 4 \mathrm{~N} 1 / 4 \mathrm{C}$ (sired by $\mathrm{N}$ bulls). The calving period was September 15 to December 15 . The calves were obtained via artificial insemination (45 days) and natural mating (45 days), using for insemination, semen from eight $\mathrm{C}$ and $\mathrm{N}$ bulls, and for the clean-up, four $\mathrm{C}$ bulls and four $\mathrm{N}$ bulls. The bulls that produced the $\mathrm{C}$ calves were the same that produced the $1 / 2 \mathrm{C} 1 / 2 \mathrm{~N}$ and $3 / 4 \mathrm{C} 1 / 4 \mathrm{~N}$ and those that produced the $\mathrm{N}$ calves, were the same that produced the $1 / 2 \mathrm{~N}^{1 / 2} \mathrm{C}$ and $3 / 4 \mathrm{~N}^{1 / 4} \mathrm{C}$.

Preceding the beginning of the experiment the cows were distributed according to the stage of fetal development, estimated by rectal palpation, genetic group and their ages, so that the treatment had the same number of animals from all the genetic groups, with similar ages and fetal development. The animals were subjected to the following grazing systems: cows kept exclusively in natural pastures, cows kept in cultivated pastures consisting of oat (Avena sativa), ryegrass (Lollium multiflorum) and clover (Trifolium vesiculosum) during the period of July 15 to September 15 and the remainder of the experiment in natural pastures; and cows kept on pastures consisting of oats, ryegrass and clover during the period of September 15 to November 15, and the remaining period on natural grassland.

For animals kept in cultivated pastures, was used an area of 18.2 ha, and 90.4 ha for animals kept in natural pastures. The stocking rates were 864 and $360 \mathrm{~kg} / \mathrm{ha}$ for cultivated and natural pasture, respectively. The estimates of available forage mass were made using the comparative method (Wilm et al., 1944) every 21 days . A composite sample was made with the samples collected to determine the availability of pasture, and from this composite two samples were taken for subsequent laboratory analysis. The forage samples were analyzed for nitrogen content $(\mathrm{N})$, using the micro-Kjeldahl method (AOAC, 1984), with subsequent multiplication by a factor of 6.25 to obtaining the $\mathrm{CP}$. The in vitro organic matter digestibility (IVOMD) of the samples was also determined following the technique of Tilley \& Terry (1963), with the qualitative values that formed the pasture feeding systems (Table 1).

Table 1. Forage mass (FM), crude protein (CP) and in vitro organic matter digestibility (IVOMD) from the pastures used during the experimental period, based on dry matter (DM)

\begin{tabular}{lcccccc}
\hline & \multicolumn{3}{c}{ Natural pasture } & \multicolumn{3}{c}{ Cultivated pasture } \\
\cline { 2 - 7 } Period & $\begin{array}{c}\mathrm{FM} \\
(\mathrm{kg} / \mathrm{h})\end{array}$ & $\begin{array}{c}\mathrm{CP} \\
(\mathrm{g} / \mathrm{kg})\end{array}$ & $\begin{array}{c}\text { IVOMD } \\
(\mathrm{g} / \mathrm{kg})\end{array}$ & $\begin{array}{c}\mathrm{FM} \\
(\mathrm{kg} / \mathrm{ha})\end{array}$ & $\begin{array}{c}\mathrm{CP} \\
(\mathrm{g} / \mathrm{kg})\end{array}$ & $\begin{array}{c}\text { IVOMD } \\
(\mathrm{g} / \mathrm{kg})\end{array}$ \\
\hline July & 2497 & 61.6 & 349.2 & 1814.4 & 151.4 & 691.2 \\
August & 1696 & 50.0 & 239.9 & 997.6 & 126.0 & 590.0 \\
September & 1380 & 51.6 & 422.8 & 995.4 & 123.0 & 696.8 \\
October & 1392 & 57.3 & 445.4 & 946.4 & 110.3 & 626.2 \\
November & 1645 & 61.4 & 473.8 & 787.2 & 73.7 & 557.9 \\
December & 1813 & 70.3 & 496.8 & & & \\
January & 1440 & 59.5 & 407.9 & & & \\
February & 1225 & 58.6 & 380.1 & & & \\
\hline
\end{tabular}

Cows were weighed at the beginning and end of the grazing periods, within the first 24 hours after calving, at weaning after 90 days and at the beginning and end of the reproductive period. The daily weight gains were determined by the weight differences between the weighings. The body condition score (BCS) assessments took place at the weighings, with assigned values of 1 to 5 , where $1=$ very thin and $5=$ very fat.

The weaning of the calves occurred during the months of December through February and were carried out in stages, as the animals reached the age 
of 90 days. Until weaning, calves remained with their dams in pasture, natural or cultivated, as previously established by the treatments. At the time of weaning, the calves were kept in a pen for 10 days and fed in troughs with chopped millet (Pennisetum americanum). Afterward the weaning stress and adaptation to feed period the calves were kept grazing in milet pastures during the summer, and fall feeding on millet with a stocking rate of eight calves/ha.

From the beginning of calving cows were placed together with teaser bulls using chin-ball markers to help identify the cows in estrus. The subsequent reproductive period was from December 1 to February 28, totaling 90 days. The reproductive method used was artificial insemination with two daily checks for estrus observation, one in the morning and one in the afternoon. The cows that manifested estrus in the morning were inseminated in the afternoon, and those who showed estrus in the afternoon were inseminated the following morning. In order to determine the interval between calving and first post-calving estrus, cows continued to be checked daily until May. Pregnancy was diagnosed 60 days after the end of the breeding season by rectal palpation.

During the experimental period the cows had free access to a mineral mix with $80 \mathrm{ppm}$ of phosphorus, consisting of common salt and dicalcium orthophosphate. Vaccinations for the control of FMD and clostridium infections were made in the periods required and recommended. The endoparasite controls were performed with strategic dosages of broad-spectrum anthelmintics and the ectoparasites (ticks, botfly larvae and myiasis) were controlled with specific products.

The experimental design was completely randomized in factorial arrangement $3 \times 4$ (three grazing strategies $\mathrm{x}$ four genetic groups) and the data were subjected to variance analysis and the $\mathrm{F}$ and Tukey tests when the $\mathrm{F}$ was significant at $5 \%$. The development and reproductive performance of cows, was analyzed using the following mathematical model:

$$
\text { Yijklmn }=\mu+\mathrm{CA} i+\mathrm{PAST} j+\mathrm{MSC} k+
$$

$\mathrm{GGCl}(\mathrm{MSC}) k+\quad(\mathrm{PAST} * \mathrm{GGC}[\mathrm{MSC}]) j k l+$

(PAST*MSC)jk + $i j k l$, where:

$\Psi i j k l=$ dependent variables; $\mu=$ general mean of all observations; CA $i=$ effect of the covariate age of cow of order " $i$ "; PAST $j=$ effect of the grazing strategies order " $\mathrm{j}$ ", where $1=$ natural pasture NP; 2 = natural pasture plus cultivated pasture; 3 = cultivated pasture plus natural pasture; MSC $k=$ effect of the mating system from which the cows originated of order "l", with 1 = purebreds and
$2=$ crossbreds F1; GGCl (MSC) $k=$ effect of the cow's genetic group order "m" with $1=$ Charolais (C); $2=$ Nellore $(\mathrm{N}) ; 3=1 / 2 \mathrm{CN}$ and $4=1 / 2 \mathrm{NC}$ within the mating system of order " $k$ "; (PAST*GGC[MSC])jkl = interaction between $\mathrm{j}$-th feeding system and k-th cow's genetic group within the $\mathrm{k}$-th mating system; (PAST*MSC) $j k=$ interaction between $\mathrm{j}$-th grazing strategies and $\mathrm{k}$-th mating system; $\varepsilon i j k l=$ residual random error, NID $(0, \sigma 2)$. The percentage variable of pregnancies was analyzed by the Chi-square test at a significance level of $5 \%$. The calf genetic group was not included in the model, because it was partially confounded with the cow genetic group.

Heterosis (H) was calculated using the following formula: $\mathrm{H}(\%)=([$ mean of crossbred animals/mean of purebred animals] -1) $* 100$.

To assess the performance of the calves the following mathematical model was used:

$\Psi i j k l=\mu$
$l(\mathrm{MSC}) k+$

$(\mathrm{PAST} * \mathrm{MSC}) j k+\varepsilon i j k l$, where:

$\Psi i j k l=$ dependant variables; $\mu=$ general mean of all observations; CA $i=$ effect of the covariate age of cow of order "i"; PAST $j=$ effect of the grazing strategies order " $\mathrm{j}$ ", where 1 = natural pasture NP; 2 $=$ natural pasture plus cultivated pasture; $3=$ cultivated pasture plus natural pasture; $\mathrm{MSC} k=$ effect of the mating system from which the calves originated of order "l", with $1=$ purebreds and $2=$ crossbreds F1 and 3 = crossbreds F2; GGCl (MSC) $k$ $=$ effect of the calves' genetic group order " $k$ " with $1=$ Charolais $(\mathrm{C}) ; 2=$ Nellore $(\mathrm{N}) ; 3=1 / 2 \mathrm{CN} ; 4=1 / 2$ $\mathrm{NC} ; 5=3 / 4 \mathrm{C} 1 / 4 \mathrm{~N}$ and $6=3 / 4 \mathrm{~N} 1 / 4 \mathrm{C}$ within the mating system of order "k"; (PAST*GGC[MSC])jkl $=$ interaction between $\mathrm{j}$-th grazing strategies and $\mathrm{k}$ th calf genetic group within the k-th mating system; (PAST*MSC) $j k=$ interaction between $\mathrm{j}$-th grazing strategies and k-th mating system; cijkl = residual random error, $\operatorname{NID}(0, \sigma 2)$.

\section{RESULTS AND DISCUSSION}

There was no significant interaction for the variables studied between grazing systems and genetic groups, thus the results are presented and discussed separately for these effects. The average weight of the cows in the beginning of the grazing period was $437 \mathrm{~kg}$ (Table 2). After the first grazing period (Sept 15) the cows grazing cultivated pastures were $53.5 \mathrm{~kg}$ heavier than the cows grazing natural pastures, resulting $12.06 \%$ more body weight. This fact is due to the better quality of food available (Table 1), which had a higher percentage of crude protein and IVOMD. This fact is important 
as the time refers to the end of the gestation period and the beginning of calving. Well-fed cows in the pre-calving, give birth more easily avoiding problems during delivery, and have greater milk production compared to cows kept in conditions of limited food production (RESTLE et al., 2005).

Table 2. Mean adjusted weights, body condition score and standard errors of the cows from the beginning of the experiment until 90 days post-calving

\begin{tabular}{lcccc}
\hline Measure & \multicolumn{3}{c}{ Grazing systems } & $\mathrm{P}<\mathrm{F}$ \\
\cline { 2 - 4 } & $\mathrm{NP}$ & $\mathrm{CP}+\mathrm{NP}$ & $\mathrm{NP}+\mathrm{CP}$ & \\
\hline Weight, kg at 07/15 & $442 \pm 9$ & $433 \pm 8$ & $437 \pm 8$ & 0.7658 \\
Weight, kg at 09/15 & $442 \pm 10^{\mathrm{b}}$ & $497 \pm 9^{\mathrm{a}}$ & $445 \pm 9^{\mathrm{b}}$ & 0.0001 \\
Weight, kg at 11/15 & $392 \pm 9^{\mathrm{c}}$ & $428 \pm 8^{\mathrm{b}}$ & $456 \pm 9^{\mathrm{a}}$ & 0.0001 \\
Weight, kg at calving & $406 \pm 10^{\mathrm{c}}$ & $452 \pm 9^{\mathrm{a}}$ & $431 \pm 9^{\mathrm{b}}$ & 0.0015 \\
Weight, kg at weaning at 90 days & $386 \pm 10^{\mathrm{b}}$ & $423 \pm 10^{\mathrm{a}}$ & $431 \pm 9^{\mathrm{a}}$ & 0.0013 \\
Body condition score at weaning at 90 days & $3.1 \pm 0.8^{\mathrm{b}}$ & $3.4 \pm 0.7^{\mathrm{a}}$ & $3.5 \pm 0.7^{\mathrm{a}}$ & 0.0056 \\
\hline
\end{tabular}

$\overline{\mathrm{a}, \mathrm{b}, \mathrm{c}}$ on the same line, followed by lower-case letters, differ $(\mathrm{P}<0.05)$ according to the Tukey test;

NP - Natural pasture from $07 / 15$ to $11 / 15$; CP+NP - Cultivated pasture from $07 / 15$ to $09 / 15$ and native pasture from $09 / 15$ to $11 / 15$; $\mathrm{NP}+\mathrm{CP}$ - Natural pasture from $07 / 15$ to $09 / 15$ and cultivated pasture from $09 / 15$ to $11 / 15$.

High body weight at calving is beneficial, as at that time cows undergo negative energy balance due to increased nutritional demands for milk production, especially when food conditions are limited, as is the case in most natural pastures. After the second grazing period (November 15) the cows kept in cultivated pastures during the second grazing period were heavier when compared with cows that were kept in natural pastures with values of 456, 428 and $392 \mathrm{~kg}$ respectively. Regardless of the grazing period, cows kept in cultivated pasture conditions had better performance because of the quality of food available.

Changes in body weights between September 15 and November 15 show losses of 50 and $69 \mathrm{~kg}$ for the cows grazing in natural pastures and a weight gain of $11 \mathrm{~kg}$ for cows kept in cultivated pastures. The weight losses of the cows kept in cultivated pastures in the first period are high, because the calving of these cows were concentrated within the second period. Therefore not all the weight loss was of body weight, but of calf weight and placental liquids expelled during calving. Beyond this fact, the greater nutrient demand from lactating cows is a determining factor in weight loss or discrete weights gains (LOBATO et al., 1998).

The best feeding conditions for the cows were in cultivated pastures with daily gains of 0.183 $\mathrm{kg} / \mathrm{day}$. This gain is crucial to increased milk production, calf performance and return to reproductive activity (CERDÓTES et al., 2004b).

The weight loss of $69 \mathrm{~kg}$ of the cows whose grazing sequence was cultivated pasture and then natural pasture is partly explained by calving and the increased development of the calf in the final trimester of pregnancy, and also the cows' transitional adaptations from cultivated pasture to a pasture of lower food quality. It should be noted that the body weight reserves achieved in the first grazing period, are extremely important due to the negative energy balance period that they experience after calving.

Even in limited food supply conditions the cows tend to maintain their milk production for the benefit of calf development and thus deplete their own body reserves in order to meet milk production demands. The supplemental feeding via grazing or supplements (CERDÓTES et al., 2004a) are tools that increase milk production of beef cows.

Average body weight at calving of cows submitted to the three feeding systems were 406, 452 and $431 \mathrm{~kg}(\mathrm{P}<0.05)$ for cows grazing on natural pastures during both periods, cultivated pastures and then natural pastures, and natural pastures and then cultivated pastures in the second period, respectively. The differences in calving weights occurred as a direct result of the feeding system used, where cows with better pre-calving conditions were heavier. Better feeding conditions pre-calving are major determinants of weight at calving for cows and calves (CERDÓTES et al., 2004a), because the greatest nutritional requirements of pregnant cows are concentrated in the final trimester of pregnancy and the first three months of lactation, as this period coincides with the subsequent cow reproduction (VAZ; LOBATO, 2010).

At weaning 90 days post-calving, average body weights were 386,423 and $431 \mathrm{~kg}$, cited in the 
order as above, with statistical differences $(\mathrm{P}<0.05)$ between cows grazing on cultivated pastures in any of the periods, as compared to those grazing exclusively on natural pastures.

The maintenance of body weight during the lactation period of the cows kept in cultivated pastures during the second period, i.e., the end of gestation and beginning of lactation, was due to the higher nutrient content supplied by the better food quality (Table 1). This fact is important because, according to data from the NRC (1996), the energy requirements of lactating cows soon after calving increase by about $65 \%$ compared to non-lactating cows maintained under conditions where limited food supply forces them to mobilize their body reserves to meet their nutritional requirements and maintain milk production. This was observed in the cows with calves, grazing on natural pastures, which contained $6.31 \%$ crude protein and $42.82 \%$ organic matter digestibility (Table 1).

According to Vaz; Lobato, (2010), lactating cows do not perform well reproductively and not provide sufficient milk for calf healthy development (RESTLE et al., 2004). These authors emphasize the high nutritional demands of cows, regardless of stage in the reproductive cycle, as there as overlaps of the nutritional demands for maintenance, milk production and reproduction throughout the year, in addition to growth when primiparous.
Body condition score at weaning at 90 days post-calving, was similar among cows grazing on cultivated pastures in either period and higher than those grazing only on in natural pastures $(\mathrm{P}<0,05)$. This fact is due to the lower food quality level of the latter with consequent lower weights at calving and weaning. Low body weight and body condition in cows during lactation means lower reproductive performance. Lobato et al. (2000) associate these facts with a combination of low availability and digestibility at the end of the natural pasture cycle and maintenance of lactation.

The average body condition of the herd is associated with the return of ovarian activity postpartum being directly linked to uterine involution and the consumption of nutrients. The weight gain of cows is an indication of fertility in cattle (ROSA et al., 2012), and the concern over satisfactory food levels in pre and post calving is so that the subsequent reproductive performance is not impaired. The higher body condition in cows kept in cultivated pastures had positive effects on subsequent reproduction (Table 3). Increases in weight and body condition scores correlate positively with increases in subsequent reproductive performance of cows (TANURE et al., 2011).

Although estrus continued to be checked after the breeding season, the estrus rates presented below (Table 3), include only those observed during the breeding season.

Table 3. Reproductive performance of beef cows kept in different grazing sequences of natural and cultivated pastures

\begin{tabular}{lccc}
\hline Measure & \multicolumn{2}{c}{ Grazing systems } \\
\cline { 2 - 4 } & $\mathrm{NP}$ & $\mathrm{CP}+\mathrm{NP}$ & $\mathrm{NP}+\mathrm{CP}$ \\
\hline Estros, \% & $67.0^{\mathrm{B}}$ & $82.0^{\mathrm{A}}$ & $75.0^{\mathrm{A}}$ \\
Pregnancy, \% & 57.0 & 65.0 & 56.0 \\
Calving, \% & $43.8^{\mathrm{B}}$ & $62.5^{\mathrm{A}}$ & $53.1^{\mathrm{A}}$ \\
Birth/estro interval, days & $118 \pm 5^{\mathrm{b}}$ & $105 \pm 5^{\mathrm{a}}$ & $103 \pm 4^{\mathrm{a}}$ \\
\hline A,B on the same line, followed by different capital letters, differ $(\mathrm{P}<0.05)$ according to the Chi-Squared test.; ${ }^{\mathrm{a}, \mathrm{b}}$ on the $^{\text {same line }}$ &
\end{tabular}

The manifestations of estrus were greater in animals that had access to cultivated pastures, $(78.5 \%)$ in relation to those kept only on natural pasture $(67 \%)$. This increased expression of estrus in the reproductive period is a consequence of the better nutritional conditions to which the cows were submitted, reflected in the higher weight and better body condition scores.

Rosa et al. (2012), working with heifers detected increased weight gains and improved reproductive performance when they were kept in improved natural pastures as compared with heifers maintained exclusively in natural pastures, linking these facts to the major input of nutrients supplied by pasture quality triggering secretion and the release of reproductive hormones.

Although there was a difference among food levels in expression of estrus, this difference was not maintained in the diagnosis of pregnancy. The cows kept in cultivated pastures in the pre-partum period maintained a numerical advantage over the other treatments. This small numerical difference in pregnancy rates is due in part to the intense management of milk production measurements of 
cows of all treatments. Although these measurements were performed every 28 days, the lots were managed weekly aside from these measurements, as the cows kept in cultivated pastures for at least one of the periods had good weight at weaning and higher pregnancy rates were expected of them.

Usually losses occur between the manifestations of estrus and diagnosis of pregnancy until the subsequent calving. In this study the losses were 17.5 and $30.1 ; 26.2$ and 4.0 and 33.9 and $5.4 \%$ for losses between the signs of estrus and pregnancy, and of pregnancy to subsequent calving, for cows maintained exclusively on natural pastures, cows kept first in cultivated pastures and then in natural pastures and cows kept first in natural pastures and then in cultivated pastures, respectively.

The losses between the manifestations of estrus and the conception of this experiment, independent of food systems, are high, demonstrating the need for a better level of nutrition for the beef herds so that the cows are in better cycle condition and are able to conceive within the subsequent reproductive period. According Byerley et al. (1987), heifers who mated in the third oestrus cycle show higher conception rates when compared with heifers who mated during the initial cycles of puberty.

The loss of pregnancies at second delivery is within acceptable standards in the literature, except for the batch of cows maintained exclusively in natural pastures, which showed a deficit of calves born of $30.1 \%$, demonstrating that even with a pregnancy similar to those diagnosed within the other food systems, these cows did not have the physiological conditions needed to carry out the pregnancy until delivery, probably due to the poor development and body condition of the cows.

Although they had a lower quality level of food, the cows grazing exclusively on natural pastures obtained repeat pregnancy rates higher than those reported in the literature (FAGUNDES et al., 2003) that associate the low reproductive rates to over-stocking and low nutritional value of the natural pastures. Better reproductive performance of cows maintained exclusively in natural pastures, by providing the animals better nutrition with management of appropriate stocking conditions (TANURE et al., 2011) and food supplementation (CERDÓTES et al., 2004a).

Vaz e Lobato (2010), not working with grazing sequences but with different weaning ages and this way subjecting batches of cows to inferior environmental conditions due to continuity and progress of lactation, verified that there were weight gains and accumulations of body condition determining the reproductive performance of cows. Often, even in adverse conditions, there exist cows with higher genetic capacity to produce in these environments. Other important factors to be considered when comparing results from the literature relate to the effects of year and place, as well as the regional climatic factors to which the results infer.

The interval between calving and the first postpartum estrus was higher in cows grazing exclusively in natural pastures when compared with the average of cows kept for any of the periods in cultivated pastures, with no difference between them of 118 days to 104 days, respectively. This shorter period of time of the animals in better feeding conditions demonstrates the high nutritional demands of cows during lactation and the need for more time to return to reproductive activity.

Tanure et al. (2011) also observed lower rates and later conceptions in the reproductive period in working with primiparous cows maintained exclusively in natural pastures when compared to cows kept in improved natural pastures in the postpartum and reproduction periods with percentages of 55.6 and $92.3 \%$, respectively, in the first half of the reproductive period.

Calving intervals are high in this study if you consider the ideal to be at most 365 days for a cow to be productive, i.e. to obtain one calf / year (VAZ; LOBATO, 2010). If we add an average gestation of 285 days in these periods of postpartum anestrus, we have calving intervals of 403 and 389 days, respectively, for cultivated and natural pastures, both being higher than one year.

The period of postpartum anestrus is influenced by body condition (TANURE et al., 2011), nutritional level before and after delivery (MONTIEL; AHUJA, 2005), the presence of the calf with its mother, lactation (VAZ; LOBATO, 2010) and the cow's age (CERDÓTES et al., 2004a).

There were differences in body weights at different periods observed between genetic groups of cows only for purebreds within the mating systems (Table 4), these differences were not observed in F1 animals. Charolais cows were heavier at all stages from the beginning of the grazing systems period with natural or cultivated pastures when compared to Nellore cows. This result is due to the breed selection where Charolais cows were selected for weight gain, this being correlated with body weight of animals, and also for the winter period, which coincided with the 
beginning of the grazing periods where Charolais have better adaptation, which does not happen with Nellore which originate in tropical regions (VAZ et al., 2012). These facts did not occur with F1 animals in which there were no differences in body development in the different phases of observation.

Table 4. Mean adjusted weights, body condition score (BCS) and standard errors of the cows from the beginning of the grazing systems until weaning in accordance with the genetic groups

\begin{tabular}{lcccccc}
\hline \multirow{2}{*}{ Genetic groups } & \multicolumn{5}{c}{ Weights, kg } & \multirow{2}{*}{ BCS } \\
\cline { 2 - 6 } & $07 / 15$ & $09 / 15$ & $11 / 15$ & Birth & Weaning & $3.1 \pm 0.7^{\mathrm{b}}$ \\
Charolais & $442 \pm 8^{\mathrm{b}}$ & $473 \pm 8^{\mathrm{a}}$ & $431 \pm 8^{\mathrm{a}}$ & $437 \pm 10^{\mathrm{a}}$ & $420 \pm 10^{\mathrm{a}}$ & $3.1 \pm 0.8^{\mathrm{b}}$ \\
Nellore & $385 \pm 2^{\mathrm{c}}$ & $403 \pm 9^{\mathrm{b}}$ & $378 \pm 9^{\mathrm{b}}$ & $379 \pm 9^{\mathrm{b}}$ & $362 \pm 8^{\mathrm{b}}$ & $3.1 \pm 0.7^{\mathrm{B}}$ \\
Average purebreds & $416 \pm 6^{\mathrm{B}}$ & $441 \pm 7^{\mathrm{B}}$ & $405 \pm 6^{\mathrm{B}}$ & $408 \pm 7^{\mathrm{B}}$ & $391 \pm 7^{\mathrm{B}}$ & $3.5 \pm 1.3^{\mathrm{a}}$ \\
$1 / 2 \mathrm{CN}$ & $468 \pm 1^{\mathrm{a}}$ & $486 \pm 14^{\mathrm{a}}$ & $441 \pm 13^{\mathrm{a}}$ & $448 \pm 14^{\mathrm{a}}$ & $441 \pm 12^{\mathrm{a}}$ & $3.5 \pm 1.1^{\mathrm{a}}$ \\
$1 / 2 \mathrm{NC}$ & $453 \pm 1^{\mathrm{a}}$ & $483 \pm 11^{\mathrm{a}}$ & $450 \pm 11^{\mathrm{a}}$ & $453 \pm 14^{\mathrm{a}}$ & $429 \pm 11^{\mathrm{a}}$ & $3.5 \pm 1.2^{\mathrm{A}}$ \\
Average F1 & $460 \pm 9^{\mathrm{A}}$ & $484 \pm 10^{\mathrm{A}}$ & $446 \pm 10^{\mathrm{A}}$ & $450 \pm 10^{\mathrm{A}}$ & $435 \pm 10^{\mathrm{A}}$ & 12.9 \\
Heterosis, \% & 10.6 & 9.75 & 10.1 & 10.3 & 11.3 & 1 \\
A,B in the same column, differ between mating systems $(\mathrm{P}<0.05)$ according to the F test; ${ }^{\mathrm{a}, \mathrm{b}}$ in the same column, differ between the \\
genetic groups (P<0.05) according to the Tukey test.
\end{tabular}

Analyzing the mating systems, F1 crossbred females had higher body weights at all stages studied and in the body condition score at weaning, with heterosis values ranging from $9.75 \%$ (at the end of the first grazing period) to $11.3 \%$ (at the time of weaning). The average body weight for heterosis was $10.4 \%$, being very similar in the different phases of observation. Performance differences between purebred and crossbred animals are due to the inverse relationship between heritability and heterosis (RESTLE et al., 2005).

The present study used cultivated pastures at certain times, but the evaluation period coincided with the end of winter and pregnancy, with subsequent calving and lactation, causing unfavorable conditions for animal production. In these situations, the use of well adapted animals is a tool to increase productivity and so is the use of crossbreds, taking advantage of the complementarity of desired characteristics in animals. Restle et al.
(2005) demonstrated a greater distance between purebred and crossbred genotypes when nutritional conditions were low, this difference decreased when the nutritional status improved, demonstrating that the purebred genotypes are more sensitive to changes in the environment.

Besides these facts, the crossbred animals probably consumed more food to meet their demands, for the greatest production potential triggered by selection or heterosis causes an increase in food consumption, as higher weight gains will depend on the availability of forage, even if the crossbred animal grazes less selectively or really takes advantage of the grazing.

Analyzing the reproductive performance of cows the purebred Charolais females had higher rates in the manifestation of estrus, pregnancy and calving, compared to Nellore, and a lower calving interval (Table 5).

Table 5. Reproductive performance of beef cows from different genetic groups

\begin{tabular}{lcccc}
\hline Genetic groups & $\begin{array}{c}\text { Estro, } \\
\%\end{array}$ & $\begin{array}{c}\text { Pregnancy, } \\
\%\end{array}$ & $\begin{array}{c}\text { Calving, } \\
\%\end{array}$ & Birth/estro interval, days \\
\hline Charolais & $80.0^{\mathrm{b}}$ & $59.5^{\mathrm{b}}$ & $57.6^{\mathrm{a}}$ & $109 \pm 3^{\mathrm{a}}$ \\
Nellore & $50.0^{\mathrm{c}}$ & $35.2^{\mathrm{c}}$ & $33.3^{\mathrm{b}}$ & $119 \pm 3^{\mathrm{b}}$ \\
Average purebeds & $65.0^{\mathrm{B}}$ & $47.4^{\mathrm{B}}$ & $45.5^{\mathrm{B}}$ & $114 \pm 3^{\mathrm{B}}$ \\
$1 / 2 \mathrm{CN}$ & $93.0^{\mathrm{a}}$ & $83.2^{\mathrm{a}}$ & $71.4^{\mathrm{a}}$ & $103 \pm 4^{\mathrm{a}}$ \\
$1 / 2 \mathrm{NC}$ & $76.5^{\mathrm{b}}$ & $61.5^{\mathrm{b}}$ & $63.2^{\mathrm{a}}$ & $103 \pm 4^{\mathrm{a}}$ \\
Average F1 & $84.8^{\mathrm{A}}$ & $72.4^{\mathrm{A}}$ & $67.3^{\mathrm{A}}$ & $103 \pm 4^{\mathrm{A}}$ \\
Heterosis, \% & 30.5 & 52.7 & 47.9 & -10.7 \\
a,b & in the same column, differ between the genetic groups $(\mathrm{P}<0.05)$ according to the Chi-Squared test; ${ }^{\mathrm{A}, \mathrm{B}}$ in the same column, differ \\
between mating systems $(\mathrm{P}<0.05)$ according to the Chi-Squared test. &
\end{tabular}


This improved reproductive performance is related to the further development of the animals (VAZ et al., 2012) and further adaptation of the Charolais cows to the environmental conditions of the present study (RESTLE et al., 2003; 2005). Charolais cows were 60.0, 69.0 and $73 \%$ higher than the Nellore, for the manifestation of estrus, pregnancy rate and calving, respectively, indicating the reproductive superiority of the Charolais compared to the Nellore in the southern part of the country. These values are higher when dealing with the heifers of the same breed mated at fourteen months of age, with values of 80.1, 129.8 and $138.8 \%$ respectively (VAZ et al., 2012). These authors suggest that Nellore females are more susceptible to reproductive losses from nonconception, maintenance of pregnancy, or the birth of calves.

Even with the use of early weaning at 90 days postpartum pregnancy rates were low in purebreds 59.5 and $35.2 \%$ for Charolais and Nellore, respectively. Among crossbred animals an increased expression of estrus and pregnancy in cows who were the daughters of Charolais bulls was observed, and is not verified in the calving rate. This better reproductive performance is probably associated with the further development of $1 / 2 \mathrm{CN}$ cows, which were heavier and in better body condition at weaning, while the Nellore were lighter and in poorer body condition than the others (Table 4). The heterosis values were $30.5,52.7$ and $47.9 \%$ for the manifestation of estrus, pregnancy rate and calving, respectively. These figures demonstrate the superiority of crossbred animals compared to the purebreds and that they are more sensitive to limiting physiological conditions such as lactation and subsequent reproduction.

Nellore had longer intervals between calving and first estrus compared with Charolais (119 vs 109 days, respectively). Among the crossbred animals no difference was observed with a value of 103 days for animals $1 / 2 \mathrm{CN}$ and $1 / 2 \mathrm{NC}$. Crossbred animals were on average 11 days earlier in the calving intervals than purebred animals, although the two groups associating the gestation period of 293 days (ALENCAR; BUGNER, 1987) with the mean interval between calving and first estrus of 109 days totaling 402 days which is above the 365 day period, demonstrating the inefficiency in the process of reproduction when a cow is not able to produce a calf every year. Values of birth intervals of less than one year are found in the literature with reduced calf weaning age (VAZ; LOBATO, 2010) or even with reduced weaning age associated with supplemental feeding of cows (CERDÓTES et al, 2004a). The feeding systems applied to the cows did not influence the birth weight of their calves (Table 6).

Table 6. Mean adjusted weights and standard errors of calves at birth, at weaning at 90 days (W90) and at 210 days (W210) of age in accordance with grazing systems and genetic groups

\begin{tabular}{lccc}
\hline Variable & Birth & W90 & W210 \\
\hline Grazing systems & & & \\
Natural pasture & $33 \pm 1.4$ & $86 \pm 3.5^{\mathrm{B}}$ & $131 \pm 5.2^{\mathrm{B}}$ \\
$\quad$ Cultivated pasture + natural pasture & $34 \pm 1.3$ & $95 \pm 3.8^{\mathrm{A}}$ & $142 \pm 4.3^{\mathrm{A}}$ \\
$\quad$ Natural pasture + cultivated pasture & $35 \pm 1.4$ & $104 \pm 4.2^{\mathrm{A}}$ & $146 \pm 5.5^{\mathrm{A}}$ \\
Genetic Groups & & & \\
Charolais & $36 \pm 1.4^{\mathrm{a}}$ & $95 \pm 6.2^{\mathrm{a}}$ & $135 \pm 8.5^{\mathrm{b}}$ \\
Nellore & $29 \pm 1.2^{\mathrm{b}}$ & $79 \pm 4.3^{\mathrm{b}}$ & $108 \pm 4.7^{\mathrm{c}}$ \\
$1 / 2 \mathrm{CN}$ & $32 \pm 1.4^{\mathrm{ab}}$ & $91 \pm 5.4^{\mathrm{ab}}$ & $164 \pm 4.2^{\mathrm{a}}$ \\
$1 / 2 \mathrm{NC}$ & $37 \pm 2.1^{\mathrm{a}}$ & $106 \pm 4.7^{\mathrm{a}}$ & $146 \pm 6.2^{\mathrm{ab}}$ \\
$3 / 4 \mathrm{CN}$ & $37 \pm 2.0^{\mathrm{a}}$ & $101 \pm 4.8^{\mathrm{a}}$ & $146 \pm 6.5^{\mathrm{ab}}$ \\
$3 / 4 \mathrm{NC}$ & $33 \pm 2.1^{\mathrm{ab}}$ & $99 \pm 6.2^{\mathrm{a}}$ & $138 \pm 7.7^{\mathrm{ab}}$ \\
\hline A,B in the same column, differ between grazing systems $(\mathrm{P}<0.05)$ according to the Tukey test; ${ }^{\mathrm{a}, \mathrm{b}, \mathrm{c}}$ in the same column, differ between \\
the genetic groups $(\mathrm{P}<0.05)$ according to the Tukey test. & & &
\end{tabular}

The heaviest calves at weaning at 90 days were the calves of cows kept in cultivated pastures during the postpartum period who obtained 0.766 $\mathrm{kg}$ /day while calves kept in pre-natal showed 0.677 $\mathrm{kg}$ /day which were higher than the $0.589 \mathrm{~kg} /$ day of calves raised exclusively on natural pastures. This greater weight gain reflected in body weight of calves is attributed to the greater weight and better 
body condition of cows which were able to keep milk production compatible with the higher weight gains of their calves.

Restle et al. (2004), working with cows grazing in natural pastures or cultivated pastures during the postpartum for a period of 180 days, observed differences in the weight gains of calves favoring the cultivated pastures, attributing this better performance to the cows' production of milk, where cows kept in natural pastures presented linearly decreasing production, and cows kept in cultivated pastures showed quadratic production, and with greater stability of production during lactation with the same variations from 5.38 to 1.97 and 5.10 to 4.84 liters / day, respectively. This higher milk production establishing further development of the calves also resulted in increased demands for maintenance and weight gain by stimulating consumption and leading to higher nutrient availability favoring their development (RESTLE et al., 2005).

The weights of the calves at 210 days of age maintained the same weight proportions as those weaned at 90 days. They were kept with their mothers in cultivated pastures for pre or postpartum. Their weights were higher than those of calves raised exclusively in natural pastures, with weight gains very similar in the post weaning. Higher weights at weaning or at 210 days are important factors in production systems, because they correlate negatively with age and slaughter weight (VAZ et al., 2011) and age of manifestation of puberty (VAZ et al., 2012).

The genetic group influenced $(\mathrm{P}<0.01)$ the birth weight of calves with the Nellore calves showing the lowest weight, with no significant difference between $1 / 2 \mathrm{CN}$ and $3 / 4 \mathrm{NC}$. Among all the genetic groups except the Nellore, there was no significant difference, only a numerical trend of increased birth weights of $1 / 2 \mathrm{NC}$ and $3 / 4 \mathrm{CN}$. Comparing the purebred animals, the higher birth weight of the Charolais in relation to the Nellore is due to the additive genetic effect for this trait, the greater size of the abdominal cavity in the Charolais cow, which allows further development of the fetus, and the increased blood flow in the uterus of European breeds in relation to zebu.

A trend that continued until weaning, even with no difference between the Charolais, $1 / 2 \mathrm{CN}, 1 / 2$ $\mathrm{NC}, 3 / 4 \mathrm{CN}$ and $3 / 4 \mathrm{NC}$, with Nellore having lower weights at all ages studied. Increased sensitivity to variation in the cow milk was also observed by Restle et al. (2004) who found higher weaning weights and higher weight gain of Charolais calves, $1 / 2 \mathrm{CN}$ and $1 / 2 \mathrm{NC}$, when compared to Nellore due to their higher energy demands due to the high potential for weight gain.

\section{CONCLUSIONS}

The use of cultivated pastures in pre and post-partum periods resulted in a better performance and higher weights and body condition at weaning at 90 days, with positive effects on expression of estrus, shorter intervals between calving and further development of the calves.

Charolais cows were heavier than the Nellore in all periods.

There were no differences between F1 cows which showed better performance than the purebreds in development and on reproductive performance.

RESUMO: Objetivou-se determinar o desempenho de 96 vacas prenhas dos grupos genéticos (GG) Charolês (C), Nelore (N), 1/2 CN e $1 / 2 \mathrm{NC}$, submetidos aos seguintes tratamentos: mantidas exclusivamente em pastagens naturais (PN) durante todo o período experimental; mantidas em pastagens cultivadas (PC) a partir de 15 de julho a 15 de setembro (PCPN) ou a partir de 15 de setembro a 15 de novembro (PNPC) e o restante do período experimental em PN. O peso no final do primeiro período de pastejo (15 de setembro) foi maior para as vacas PCPN que as do PNPC e PN. O peso no final do segundo período (15 de novembro) foi de 456, 428 e $392 \mathrm{~kg}$, respectivamente, para PNPC, PCPN e PN. No parto as vacas da PCPN foram mais pesadas, seguidas pela PNPC e a PN. Ao desmame 90 dias de pós-parto o grupo mais pesado era de vacas da PNPC, seguido pelo PCPN e PN. Vacas N foram menos pesadas em todas as avaliações, seguidas pelas C, com o peso dos F1s maior do que os puros. As sequiências de pastagem não afetaram os percentuais de vacas em cio e prenhes, mas influenciou os intervalos entre partos e pós-parto ao primeiro cio (IPC). O GG influenciou a taxa de vacas em estro, prenhes e IPC que foi menor nas F1 (103 dias), seguidas das C (109 dias) e as N tiveram o maior intervalo (119 dias). As sequencias de pastejo influenciaram o ganho de peso médio diário (GMD) de bezerros até a idade do desmame aos 90 dias de idade. O GG do bezerro afetou a GMD até os 210 dias.

PALAVRAS-CHAVE: Charolês. Cruzamento. Estro. Heterose. Nelore. Prenhez. 


\section{REFERENCES}

ALENCAR, M. M., BUGNER, M. Desempenho produtivo das raças Canchim e Nelore II. Primeiro parto. Pesquisa Agropecuária Brasileira, Brasília, v. 22, n. 8, p. 867-872, 1987.

ASSOCIATION OF OFFICIAL ANALYTICAL CHEMITS - AOAC. Official methods of analysis. 14 ed. Washington, D. C., 1984.1141p.

BERETTA, V.; LOBATO, J. F. P.; MIELITZ NETO, C. G. A. Produtividade e eficiência biológica de sistemas de produção de gado de corte de ciclo completo no Rio Grande do Sul. Revista Brasileira de Zootecnia. Viçosa, v. 31, n. 2 (supl.), p. 991-1001, 2002.

BYERLEY, D. J.; STAIGMILLER, R. B.; BERARDINELLI, J. G.; SHORT, R. E. Pregnancy rates of beef heifers bred either on puberal or third estrus. Journal of Animal Science, Champaign, v. 65, n. 5, p. 645-650, 1987.

CERDÓTES, L.; RESTLE, J.; BRONDANI. I. L.; OSMARI, E. K.; SOCCAL, D. C.; SANTOS, M. F. Desempenho produtivo de vacas de quatro grupos genéticos submetidas a diferentes manejos alimentares, desmamadas aos 42 ou 63 dias de idade. Revista Brasileira de Zootecnia. Viçosa, v. 33, n. 3, p. 585-596, 2004a.

CERDÓTES, L.; RESTLE, J.; ALVES FILHO, D. C.; PACHECO, P. S.; MISSIO, R. L.; GARAGORRY, F. C. Desenvolvimento de bezerros de corte filhos de vacas submetidas a diferentes manejos alimentares, desmamados aos 42 ou 63 dias de idade. Revista Brasileira de Zootecnia. Viçosa, v. 33, n. 3, p. 597-609, $2004 b$.

FAGUNDES, J. I. B.; LOBATO, J. F. P.; SCHENKEL, F. S. Efeito de duas cargas animais em campo nativo e de duas idades a desmama no desempenho de vacas de corte primíparas. Revista Brasileira de Zootecnia. Viçosa, v. 32, n. 6 (supl.1), p. 1722-1731, 2003.

LOBATO, J. F. P.; ZANOTTA JUNIOR, R. L. D.; PEREIRA NETO, O. A. Efeitos da dieta pré e pós-parto na eficiência reprodutiva de vacas primíparas de corte. Revista Brasileira de Zootecnia. Viçosa, v. 27, n. 5, p. 857-862, 1998.

LOBATO, J. F. P.; MÜLLER, A.; PEREIRA NETO, O. A.; OSÓRIO, E. B. Efeitos da idade à desmama sobre o desempenho reprodutivo de vacas de corte primíparas. Revista Brasileira de Zootecnia. Viçosa, v. 29, n. 6 (supl.1), p. 2013-2018, 2000.

MONTIEL, F.; AHUJA, C. Body condition and suckling as factors influencing the duration of postpartum anestrus in cattle: a review. Animal Reproduction Science, Amsterdan, v. 85, p. 1-26, 2005. http://dx.doi.org/10.1016/j.anireprosci.2003.11.001

RESTLE, J.; PACHECO, P. S.; MOLETTA, J. L.; BRONDANI, I. L.; CERDOTES, L. Grupo genético e nível nutricional pós-parto na produção e composição do leite de vacas de corte. Revista Brasileira de Zootecnia. Viçosa, v. 32, n. 3, p. 585-597, 2003.

RESTLE, J.; PACHECO, P. S.; PASCOAL, L. L.; PÁDUA, J. T.; MOLETTA, J. L.; FREITAS, A. K.; LEITE, D. T. Efeito da pastagem, da produção e composição do leite no desempenho de bezerros de diferentes grupos genéticos. Revista Brasileira de Zootecnia. Viçosa, v. 34, n. 5, p. 691-703, 2004.

RESTLE, J.; PACHECO, P. S.; PÁDUA. J. T.; MOLETTA, J. L.; ROCHA, M. G.; SILVA, J. H. S.; FREITAS, A. K. Efeitos da taxa de ganho de peso pré-desmama de bezerras de corte e do nível nutricional pós-parto, quando vacas, sobre a produção e composição do leite e o desempenho de bezerros. Revista Brasileira de Zootecnia. Viçosa, v. 34, n. 1, p. 197-208, 2005. 
ROSA, A. A. G.; VAZ, R. Z.; LOBATO, J. F. P. Natural and improved pastures on the growth and reproductive performance of Hereford heifers. Revista Brasileira de Zootecnia. Viçosa, v. 41, n. 1, p. 203211, 2012.

TANURE, S.; PÖTTER, B. A. A.; LOBATO, J. F. P. Natural and improved natural pastures on the reproductive performance of first-calf beef cows. Revista Brasileira de Zootecnia, Viçosa, v. 40, n. 3, p. 690699, 2011.

TILLEY, J. M. A.; TERRY, R. A. A. Two stage technique for the "in vitro" digestion of forage crops. Journal of British Grassland Society. Hurley, v. 18, n. 2, p. 104-111, 1963.

VAZ, R. Z.; LOBATO, J. F. P. Effects of the weaning age of calves on somatic development and on reproductive performance of beef cows. Revista Brasileira de Zootecnia, Viçosa, v. 39, n. 5, p. 1058-1067, 2010.

VAZ, R. Z.; LOBATO, J. F. P.; PASCOAL, L. L. Desenvolvimento de bezerros de corte desmamados aos 80 ou 152 dias até os 15-16 meses de idade. Revista Brasileira de Zootecnia, Viçosa, v. 40, n. 1, p. 221-229, 2011.

VAZ, R. Z., RESTLE, J.; PACHECO, P. S.; VAZ, F. N.; PASCOAL, L. L.; VAZ, M. B. Ganho de peso pré e pós-desmame no desempenho reprodutivo de novilhas de corte aos quatorze meses de idade. Ciência Animal Brasileira, Goiânia, v. 13, n. 2, p. 272-281, 2012. http://dx.doi.org/10.5216/cab.v13i3.17527

WILM, H. G.; COSTELLO, D. F.; KLIPPLE, G. E. Estimating forage yield by the double sampling methods. Journal of the American Society of Agronomy, Geneva, v. 36, p. 194-203, 1944.

http://dx.doi.org/10.2134/agronj1944.00021962003600030003x 